\title{
Efficacy of a commercial disinfectant against Vibrio ordalii, Vibrio anguillarum, Francisella sp. and Infectious Pancreatic Necrosis Virus (IPNV) pathogens of Atlantic salmon (Salmo salar) farmed in Chile
}

\author{
Eficacia de un desinfectante sobre Vibrio ordalii, Vibrio anguillarum, Francisella sp. \\ y Virus de la Necrosis Pancreática Infecciosa (IPNV), patógenos de salmón \\ del Atlántico (Salmo salar) cultivado en Chile \\ M Mullera ${ }^{a}$ P Ilardi ${ }^{b}$, R Avendaño-Herrera ${ }^{*}$ \\ aAQUAFARMA, División de Acuicultura, Veterquímica S.A., Puerto Montt, Chile. \\ bLaboratorio de Investigación y Desarrollo-Veterquímica, Cerrillos, Santiago, Chile. \\ ${ }^{c}$ Universidad Andrés Bello, Facultad de Ciencias Biológicas, Departamento de Ciencias Biológicas, Viña del Mar, Chile.
}

\begin{abstract}
RESUMEN
En el presente trabajo se evaluó la eficacia in vitro del desinfectante Duplalim ${ }^{\circledR}$, una combinación sinérgica de glutaraldehído y sales de amonio cuaternario de cuarta generación, contra 4 patógenos de peces prevalentes de la salmonicultura chilena. Los resultados muestran que todas las concentraciones ensayadas (diluciones entre 1:200 a 1:400) fueron eficaces sobre los aislados de Vibrio ordalii y Vibrio anguillarum post-30 s de exposición, detectando niveles de reducción igual a $1.8 \times 10^{6} \mathrm{UFC} / \mathrm{ml}$. Concentraciones superiores de Duplalim ${ }^{\circledR}$ (dilución 1:50) y un tiempo de exposición no menor a 5 min. fueron necesarios para eliminar completamente al patógeno intracelular Francisella sp. Cuando el desinfectante fue ensayado contra el Virus de la Necrosis Pancreática Infecciosa (IPNV), se detectó que la dilución 1:400 tiene un efecto significativo después de 2 minutos sin importar los títulos de IPNV testeados (mayor concentración evaluada $10^{7.6} \mathrm{TCID}_{50} / \mathrm{ml}$ ). Duplalim ${ }^{\circledR}$ se evaluó en condiciones masivas contra los miembros de la familia Vibrionaceae. En comparación a los controles (sin adición desinfectante), la dilución 1:400 de Duplalim ${ }^{\circledR}$ eliminó completamente V. ordalii y V. anguillarum después de 15 minutos de tratamiento, tanto en el agua de cultivo como en la superficie de mallas usadas en el cultivo del salmón. Así, el análisis microbiológico del agua de los controles mostró concentraciones de $1.4 \pm 0.3 \times 10^{6} \mathrm{UFC} / \mathrm{ml}$, mientras en el caso de las mallas $7.6 \pm 3.2 \times 10^{5} \mathrm{UFC} / \mathrm{ml}^{1}$. En resumen, los antecedentes obtenidos indican que el uso del desinfectante Duplalim ${ }^{\circledR}$ es efectivo contra V. ordalii, V. anguillarum y IPNV en bajas concentraciones y cortos periodos de exposición (dilución 1:400 por $15 \mathrm{~min}$.), mientras que para el patógeno intracelular se requiere una concentración mayor.
\end{abstract}

Key words: disinfectant, Chilean fish pathogens, Atlantic salmon.

Palabras clave: desinfectante, patógenos de peces, salmón del Atlántico.

\section{INTRODUCTION}

Fish diseases of major importance in Chilean salmon farming includes infectious pancreatic necrosis (IPN) and Piscirickettsia salmonis (Fryer and Hedrick 2003), which cause significant economic losses due to mortalities of Atlantic salmon, Salmo salar, fry and post-smolt in seawater. In addition, an increase in disease detection of emergent pathogens as Vibrio ordalii (Colquhoum et al 2004), Streptococcus phocae (Gibello et al 2005, Romalde et al 2008), Francisella (Birkbeck et al 2007) and, lately, Vibrio anguillarum (Avendaño-Herrera et al 2007) has been observed in the last decade. To date, economic losses caused by these bacterial pathogens, except $V$. ordalii, have decreased; however, it remains one of the

Accepted: 18.08.2010.

*rravendano@unab.cl, reavendano@yahoo.com most important pathogen in the salmon industry in Chile because no commercial vaccines are available. In general, most treatments proposed for the outbreaks are based on the administration of drugs through feed. Considering that a selective effect of antimicrobial use on the emergence of resistant fish bacteria has been documented in several reports (Smith et al 1994, Alderman and Hastings 1998), alternative treatments to the use of drugs are necessary.

In salmonids aquaculture facilities, disinfectants are vital tools for effective farm biosecurity, used to reduce pathogenic microorganisms on biological surfaces by rather non-specific actions. They include iodophores used for eggs and equipment disinfectants, salts, organic chlorocompounds (e.g. chloramines-T), aldehydes (e.g. formalin), hydrogen peroxide and quaternary ammonium compounds (e.g. benzalkonium chloride) (Burka et al 1997). The majority of these chemicals have also been used to inactivate bacterial and virus pathogens on contaminated rearing equipment, seawater pipes, air hoses, tanks, and nets as well as the hands and feet of the working staff. Besides its disinfecting 
properties, few studies have been designed to assess the quaternary ammonium compounds, particularly a synergistic blend of superquats and glutaraldehyde (Duplalim ${ }^{\circledR}$, Veterquímica S.A., Chile), which is commercialized as a disinfectant of broad spectrum, presenting fast action and low toxicity. For these reasons, the aims of this study were to determine the efficacy of Duplalim ${ }^{\circledR}$ in treating various fish pathogens under in vitro conditions and large scale and validate the treatment regimes for controlling these diseases in salmon production.

\section{MATERIAL AND METHODS}

This study was done in two experimental stages: I) In vitro susceptibility of the extracellular bacteria V. ordalii and V. anguillarum, intracellular pathogens as Francisella sp. and IPNV. II) Large scale assays conducted at the hatchery of the Laboratory of Research and Development at Veterquímica. The experiments 1 and 2 of the stage I was carried out in triplicate for each bacterial strain, while the experiment 3 considered the use of IPNV.

\section{STAGE I: IN VITRO ASSAYS IN LABORATORY}

\section{EXPERIMENT 1}

The effectiveness of different Duplalim ${ }^{\circledR}$ treatments against $V$. ordalii and V. anguillarum was assessed following the procedures of Avendaño-Herrera et al (2006). The $V$. ordalii strains used in this work, Au2, Au3 and PF180, were isolated in Chile during 2003-2005 from clinically infected Atlantic salmon (Silva-Rubio et al 2008 ${ }^{\mathrm{a}}$ ). In the case of $V$. anguillarum, three strains isolated from Atlantic salmon coded as PF2, PF7 and PF8 and belonging to serotype O3 of this fish pathogen (Silva-Rubio et al $2008^{\mathrm{b}}$ ) were employed. The reference strains of Vibrio ordalii ATCC $33509^{\mathrm{T}}$ and Vibrio anguillarum ATCC 43307 from the American Type Culture Collection were used for comparative purposes. The experimental assays were conducted in sterile 6-well Multidishes (Nunclon ${ }^{\mathrm{TM}}$ Surface) containing $10 \mathrm{ml}$ of natural sterilized (filtered and autoclaved) seawater. Inocula were prepared from bacteria grown on tryptone soy agar (Oxoid) supplemented with $1 \% \mathrm{NaCl}$ (Winkler) plates (TSA-1), washed in $0.85 \%$ sterile saline solution (SS), resuspended and diluted in SS, and then each well was seeded with 500 $\mu l$ of the bacterial suspension to achieve an initial V. ordalii and $V$. anguillarum concentration of $5 \times 10^{6}$ cells $\mathrm{ml}^{-1}$ as determined by direct microscopy count (equivalent to $1.8 \times 10^{6} \mathrm{CFU} \mathrm{x} \mathrm{m}{ }^{-1}$, respectively). After a stabilization period of $30 \mathrm{~min}$. at $19 \pm 1^{\circ} \mathrm{C}$, susceptibility of each fish pathogens and bacterial strain to different Duplalim ${ }^{\circledR}$ concentrations was examined in triplicate, adding this chemical compound to $1: 200 ; 1: 300$ and 1:400 dilutions. Duplalim ${ }^{\circledR}$ was evaluated during 30, 60, 120 and $180 \mathrm{~s}$ at $20^{\circ} \mathrm{C}$. Controls without the addition of the disinfectant were run simultaneously in exactly the same conditions as described above.

To determine the cultivable cells in the seawater, samples of $0.5 \mathrm{ml}$ were taken aseptically, after each treatment. All samples were serial-diluted in SS and $0.1 \mathrm{ml}$ of each dilution was plated in duplicate on TSA-1 plates for the count of total heterotrophic marine bacteria. After incubation, biochemical identification tests (API20E; Biomèrieux) and slide agglutination tests (Silva-Rubio et al 2008 ${ }^{\mathrm{a}}$, b) were carried out to determine the presence of the inoculated $V$. ordalii and V. anguillarum strains in each Multidish.

\section{EXPERIMENT 2}

The Francisella sp. strain used in this work was isolated in Chile in 2006 from spleen of clinically infected Atlantic salmon. To determine the effect of different Duplalim ${ }^{\circledR}$ concentrations on Francisella sp, bactericidal assays were conducted according to a previously described protocol of Avendaño-Herrera et al (2006) with minor modification.

Pure colonies of Francisella sp. cultivated at $20{ }^{\circ} \mathrm{C}$ were picked up from cysteine heart agar (Difco ${ }^{\mathrm{TM}}$ ) plates containing 5\% sheep blood (Olsen et al 2006), adjusted in sterile freshwater to contain $3 \times 10^{8} \mathrm{CFU} \mathrm{x} \mathrm{ml}^{-1}$. Duplalim ${ }^{\circledR}$ was evaluated during 2, 5 and 15 min treatment periods for the control of Francisella sp. using diluted disinfectant to a 1:50;1:200 and 1:400 concentrations. Francisella sp. controls were run simultaneously without the addition of the disinfectant. The experiment was also carried out in triplicate.

Treatments were considered effective if a pure culture of grey white, slightly mucoid convex colonies of Francisella sp. was absent when the samples which were taken aseptically at the end of the incubation period were spread onto media.

\section{EXPERIMENT 3}

Infectious pancreatic necrosis virus (IPNV) strain 483, of the serotype $\mathrm{Sp}$, originated from an outbreak in Salmo salar cultured in Chile in 2005, was used for the assay. The virulent IPNV isolate was previously identified from tissue according to Espinoza and Kuznar (2002). The virus was subjected to two rounds of plaque purification on Chinook salmon embryo cells (CHSE-214) before propagation in the same fish cell line to obtain a stock (Johansen and Sommer 2001). The infected cell cultures were kept frozen at $-80^{\circ} \mathrm{C}$ until they were used. A small aliquot of the material was frozen separately and was used for the determination of $\mathrm{TCID}_{50}(50 \%$ tissue culture infective dose) by end-point dilution (Reed and Muench 1938). The experimental assays were conducted in sterile 6-well Multidishes (Nunclon ${ }^{\mathrm{TM}}$ Surface) containing $10 \mathrm{ml}$ of the CHSE-214 with IPNV at titres of $10^{5.6} ; 10^{6.6}$ and $10^{7.6}$ TCID $_{50} \mathrm{ml}^{-1}$. Susceptibility of IPNV to Duplalim ${ }^{\circledR}$ was examined in triplicate, with 
the addition of this chemical compound at final dilution of $1: 400$, and then incubated for 2,5 and $15 \mathrm{~min}$ at $19 \pm 1^{\circ} \mathrm{C}$. The action of the disinfectant was stopped using a specific neutralizer (polysorbate 80 (3\%), lecithin $3 \mathrm{~g} / \mathrm{L}$, sodium thiosulphate $5 \mathrm{~g} / \mathrm{L}$, L-histidine $1 \mathrm{~g} / \mathrm{L}$ and saponin $30 \mathrm{~g} / \mathrm{L}$ ), which was validated for all disinfectants before use in the tests. Negative controls, consisted of a harvested cell culture medium from uninfected cell cultures exposed to the same Duplalim ${ }^{\circledR}$ concentration but not inoculated with IPNV. The infected cell cultures but not treated with the disinfectant were included as positive controls. All controls were run simultaneously in the exact same conditions as described above.

To test the efficacy of superquats and glutaraldehyde compounds to inactivate IPNV, $0.5 \mathrm{ml}$ aliquots of the virus solution were taken aseptically and transferred to plates containing the CHSE-214 cells. Each sample was passaged three times every seven days and incubated at $18^{\circ} \mathrm{C}$. The cytopathic effect was observed by inverted microscopy for up to 7,14 and 21 days post-infection.

Moreover, attempt was made to check if the inhibition caused by Duplalim ${ }^{\circledR}$ was produced only by the disinfectant or contributed to the persisted active residues in the media. The IPNV isolate 483 was cultured as previously described and concentrated by successive ultrafiltrated steps until $10^{15} \mathrm{TCID}_{50} / \mathrm{ml}$ was obtained. Two aliquots of $5 \mathrm{ml}$ each was taken, one of them being used as control (no disinfectant added) and the other aliquot treated with Duplalim ${ }^{\circledR}$ at final dilution of 1:400, followed by incubation for $2 \mathrm{~min}$ at $18^{\circ} \mathrm{C}$. Each solution was transferred to a Centricon ultrafiltration device with $10-\mathrm{kDa}$ molecular mass cutoff (Millipore), and supernatants were removed by centrifugation $\left(3500 \mathrm{x} \mathrm{g}\right.$ for $60 \mathrm{~min}$ at $4{ }^{\circ} \mathrm{C}$ ). IPNV were resuspended in phosphate buffered saline ( $\mathrm{pH}$ 7.4) and dialysis was repeated until a concentration of residual Duplalim $^{\circledR}$ reached 1:10000 dilutions. The control sample (without disinfectant) was treated in the same way. Finally, $100 \mu \mathrm{l}$ of the treatment and control were left in a 24-well plate containing CHSE-214 cells and mixed. Serial ten-fold dilutions (from $10^{-1}$ to $10^{-5}$ ) were made in quadruplicate and then incubated at $18{ }^{\circ} \mathrm{C}$ for two weeks. Each plate was observed by inverted microscopy for the appearance of cytopathic effect for 7 and 14 days.

\section{STAGE II: LARGE SCALE ASSAY}

To mimic a "near real-life" the assays for the evaluation of Duplalim ${ }^{\circledR}$ was performed in buckets containing $10 \mathrm{~L}$ of $0.45 \mu \mathrm{m}$ filtered seawater. Four buckets were inoculated with the strains of $V$. anguillarum $\mathrm{Au} 2$ and $V$. ordalii $\mathrm{PF} 2$ at a final concentration of $1.8 \times 10^{6} \mathrm{CFU} \mathrm{x} \mathrm{ml}{ }^{-1}$ of a $1: 1$ mix concentration. Each bucket was seeded with the bacterial suspension prepared as described for experiment 1 and homogenized with a fish net for $60 \mathrm{~s}$. Each fish net was maintained inside the buckets. Following a 30 min acclimatization period, addition of Duplalim ${ }^{\circledR}$ at a concentration of 1:400 was performed to two buckets, while the remaining inoculated buckets without the disinfectant were considered as positive controls. The negative control corresponded to a new bucket with only seawater, no bacteria nor chemical disinfectant added.

In order to evaluate the effect of Duplalim ${ }^{\circledR}$ on the microorganisms attached to the surface of the fishing net (net used in salmon cages) at the end of incubation ( $24 \mathrm{~h}$ ), the thread mesh of each experimental set was sampled. For this, ten pieces of net were carefully cut into $1 \mathrm{~cm}^{2}$ pieces, washed repeatedly with SS and put into Falcon tubes containing $10 \mathrm{ml}$ of SS. The bacteria that were attached to the pieces of mesh were removed using an Ultrasonics Homogenizer for 15 seconds.

Bacteriological sampling of water was carried out at $15 \mathrm{~min}, 4 \mathrm{~h}$ and $24 \mathrm{~h}$ post-treated with Duplalim ${ }^{\circledR}$. Samples were serial diluted in SS and $0.1 \mathrm{ml}$ of each dilution was plated on TSA-1 for the total count of Vibrionaceae. To increase the sensitivity of the technique, samples of $1 \mathrm{ml}$ were taken directly from the water of each bucket and seeded onto the same bacteriological medium. The plates were incubated at $20^{\circ} \mathrm{C}$ for one week. After incubation, selective counts of CFU (according to the morphotypes grown on TSA-1 plates) and confirmation by serological identification tests (i.e. slide agglutination assays) according to Silva-Rubio et al $\left(2008^{\mathrm{a}, \mathrm{b}}\right)$ were carried out to determine the presence of each bacterium inoculated in seawater.

\section{RESULTS AND DISCUSSION}

The addition of Duplalim ${ }^{\circledR}$ at concentrations among 1:200 to 1:400 to seawater killed completely $V$. ordalii and $V$. anguillarum in all in vitro treatments, regardless of the period tested and strains used. In contrast, there was no loss of viability in the un-disinfectant controls with values of $1.6 \pm 0.56 \times 10^{6} \mathrm{CFU} \mathrm{x} \mathrm{ml}{ }^{-1}$ for $V$. anguillarum, and $1.4 \pm 0.97 \times 10^{6} \mathrm{CFU} \mathrm{x} \mathrm{ml}^{-1}$ for V. ordalii (similar to initial inoculate of each pathogen).

The addition of Duplalim ${ }^{\circledR}$ to freshwater killed completely Francisella sp. at a concentration of 1:50 within 5 and $15 \mathrm{~min}$. (table 1). When the concentration of the disinfectant was decreased, a higher degree of resistance to Duplalim ${ }^{\circledR}$ was observed. Interestingly, in freshwater with a dilution of 1:400, Francisella sp. cells were recovered regardless the incubation time. Similar cultivability pattern to Francisella sp. cells was observed in the negative control groups (without disinfectant). In spite of the limited number of the isolates tested (only one) it seems that Francisella sp., an intracellular facultative microorganism, had the highest resistance to Duplalim ${ }^{\circledR}$ than the extracellular pathogens such as V. ordalii and V. anguillarum. In a recent study, Verner-Jeffreys et al (2009) reported that two Gram-positive bacteria (Lactococcus garviae and Carnobacterium piscicola) were apparently more resistant to four biocide products than other two 
Table 1. In vitro bactericidal effect of Duplalim® on Francisella sp. at $20^{\circ} \mathrm{C}$. sp. a $20^{\circ} \mathrm{C}$.

Efecto bactericida in vitro de Duplalim ${ }^{\circledR}$ en Francisella

\begin{tabular}{lcccc}
\hline \multicolumn{1}{c}{ Duplalim $^{\circledR}$} & & \multicolumn{3}{c}{ Exposure time (min) } \\
\cline { 3 - 5 } \multicolumn{1}{c}{ dilutions } & & 2 & 5 & 15 \\
\hline Untreated-control & & $+++^{\mathrm{a}}$ & +++ & +++ \\
$1: 50$ & & + & - & - \\
$1: 200$ & & +++ & ++ & - \\
$1: 400$ & & +++ & +++ & ++ \\
\hline
\end{tabular}

a Data correspond to the results of the Francisella sp. isolate in triplicate.

- Effective (no CFU after exposure).

Growth of Francisella sp.:,$+<10^{2} ;++, 10^{3}$ and,$+++>10^{5}$.

Gram-negative pathogens. In general, in the case of the Gram-positive bacteria it is suggested that the presence of some cell structures (i.e. capsular material) may confer resistance to antibacterial compounds (i.e. activity of serum). Considering that Francisella sp. replicates and grows within the membrane-bound cytoplasmatic vacuoles of infected host cells (Olsen et al 2006) the resistance shown by the isolate to Duplalim ${ }^{\circledR}$ might be explained by the low concentration that can be attained by this disinfectant compound. Until now, the molecular base of this resistance is unknown. Further studies are needed to elucidate the composition and chemical structure and/ or the role of some enzyme produced by Francisella in its protection.

The survival capacity of the IPNV isolate 483 in the CHSE-214 cells after the Duplalim ${ }^{\circledR}$ treatments is shown in table 2. The concentration of the disinfectant had a significant effect with 2, 5 and 15 min. of exposure, regardless of the IPNV titres employed (until a concentration of $10^{15} \mathrm{TCID}_{50} \mathrm{ml}^{-1}$ ). As expected, the results of cytopathic effect test showed that IPNV produced degenerative changes in the CHSE cell line without disinfectant passed three times. On the other hand, it is important to denote that the action of active residues was efficiently stopped with the addition of the neutralizer as well as by the dialysis procedures. Therefore, no toxicity of the disinfectant and solvent either detected over the cells. In fact, after incubation (IPNV with and/ or without Duplalim ${ }^{\circledR}$ ) only total cytopathic effect was detected in the CHSE-214 plates without the disinfectant, therefore, IPNV was re-isolated at $10^{-5}$ serial dilutions during two weeks.

Table 2. Effect of Duplalim ${ }^{\circledR}$ at final dilution of 1:400 on in vitro inactivation of Infectious Pancreatic Necrosis Virus. Efecto de Duplalim ${ }^{\circledR}$ en dilución final de 1:400 sobre la inactivación in vitro del Virus de la Necrosis Pancreática.

\begin{tabular}{|c|c|c|c|c|}
\hline Titre viral $\left(\mathrm{TCID}_{50} / \mathrm{ml}\right)$ & Exposure time (min) & Passage $1^{a}$ & Passage 2 & Passage 3 \\
\hline \multirow[t]{4}{*}{$10^{5.6}$} & 2 & - & - & - \\
\hline & 5 & - & - & - \\
\hline & 15 & - & - & - \\
\hline & Untreated-control & + & + & + \\
\hline \multirow[t]{4}{*}{$10^{6.6}$} & 2 & - & - & - \\
\hline & 5 & - & - & - \\
\hline & 15 & - & - & - \\
\hline & Untreated-control & + & + & + \\
\hline \multirow[t]{4}{*}{$10^{7.6}$} & 2 & - & - & - \\
\hline & 5 & - & - & - \\
\hline & 15 & - & - & - \\
\hline & Untreated-control & + & + & + \\
\hline \multirow[t]{2}{*}{$10^{15}$} & 2 & - & - & - \\
\hline & Untreated-control & + & + & + \\
\hline
\end{tabular}

a Three replicates per passage.

- Effective (no cytopathic effect after exposure).

$+\quad$ Positive Sample for IPNV with an extensive cytopathic effect of approximately $90 \%$ was observed at 7 days. 
In general, most of the disinfection studies in IPNV have been carried out using other chemical disinfectants such as iodine, chlorine and formalin. Both iodine and chlorine inactivated IPNV, although the efficacy depended on the $\mathrm{pH}$, virus concentration and the presence of organic matter in water (Elliott and Amend 1978). Studies of Desaultes and MacKelvie (1975) reported that a 30 min exposure to chlorine at a concentration of $40 \mathrm{ppm}$ effectively inactivates a concentration of $10^{7.5} \mathrm{TCID}_{50 /} \mathrm{ml}$, while using $35 \mathrm{ppm}$ iodine for the same time is appropriate to eradicate a concentration of $10^{6.6} \mathrm{TCID}_{50 /} \mathrm{ml}$. These authors also denoted that although formalin exhibited some virucidal activity, it was not a good choice for the inactivation of IPNV (MacKelvie and Desaultes 1975).

With the aim to asses if Duplalim ${ }^{\circledR}$ can be a suitable candidate for the treatment of seawater and surface of tanks, nets and/or rearing equipment, bioassays were performed in buckets with seawater containing a mesh to stop fish and seeded with two different fish pathogens. In this study, members of the genus Vibrio were selected because they constitute part of the microbiota of marine fish as well as part of the normal microbiota of the aquatic environment, and therefore present a constant threat for any susceptible host (Austin and Austin 2007). The culture of $V$. ordalii and V. anguillarum in the buckets treated with 1:400 disinfectant concentrations had a significant effect on the survival of the microbiota in the seawater, with no viable bacteria being detectable from 15 min post-treatment. In contrast, controls without the addition of Duplalim ${ }^{\circledR}$ maintained $1.37 \pm 0.29 \times 10^{6} \mathrm{CFU} / \mathrm{ml}$ during the experiment. Similarly, there was no evidence of Vibrionaceae culture adhered on the fishing net compared to untreated Duplalim ${ }^{\circledR}$ tries. It is important to note that survival for an aquatic bacterium in seawater outside the fish host may depend on biofilm formation. V. anguillarum is normally found attached to surfaces, as opposed to a free-swimming form, which is likely to provide an adaptive or survival advantage for bacteria in the aquatic environment (Costerton et al 1987, 1995). In each of these environments, the bacterium likely utilizes its external membrane to protect its intracellular contents from damaging agents or conditions (Wang et al 2003). When attempt of resuscitation of the non-culturable bacteria with the addition of fresh medium was employed, no cells from the mesh samples were recovered onto TSA-1 (data not shown), indicating that all microorganisms were completely killed.

On the other hand, cultivable bacteria remained constant in the positive controls (without the disinfectant), regardless of the period sampled, and showing an average value of $1.4 \pm 0.3 \times 10^{6} \mathrm{CFU} / \mathrm{ml}$. The bacteria adherence on the mesh without exposure to the disinfectant was about $55.3 \%\left(7.6 \pm 3.2 \times 10^{5} \mathrm{CFU} / \mathrm{ml}\right)$ lower in concentration than those containing in the seawater after $24 \mathrm{~h}$. Selective counts of V. anguillarum on TSA-1 sampled from the buckets with no treatment represented an average of $49.7 \%$ of the total microbiota counted. As expected, seawater without the mixed bacteria and disinfectant remained with a low load of bacteria $\left(6.3 \times 10^{5} \mathrm{CFU} \times \mathrm{ml}^{-1}\right)$ through the entire period of the study.

Although Duplalim ${ }^{\circledR}$ is one of the most used disinfectants in the Chilean salmon industry, it has been legally registered and recently validated to be used against Infectious Salmon Anaemia Virus (ISA) virus and its effective use may be well established in this study; we cannot discard that organic matter present in the water column or dirty conditions in the water could interfer on the efficiency of the disinfectant. Studies are being carried out to test this condition using the Verner-Jeffreys et al (2009) protocol.

It can be concluded that, apart from the fact that in this work we used a methodology that is different to the test standards used for the evaluation of bactericidal and virucidal activity of disinfectants and antiseptics for use in the veterinary field published recently by VernerJeffreys et al (2009), our results demonstrate that the use of Duplalim ${ }^{\circledR}$ in aquaculture is effective in low concentration and short time of exposure (15 min. at a concentration of 1:400 dilutions), with the exception of the intracellular pathogen used in this work. It is important to highlight that Verner-Jeffreys et al (2009) tested disinfectants of different nature than Duplalim ${ }^{\circledR}$ (i.e. hydrogen peroxide, peracetic acid, acidic iodophore and Chloramine $\mathrm{T}$ ) and suggested that when studying other desinfectants (i.e. superquats and glutaraldehyde), the procedure can be adopted or modified to be used in countries outside Europe. Therefore, the use of Duplalim ${ }^{\circledR}$ may be appropriate as a general preventive disinfection method against $V$. ordalii, V. anguillarum and IPNV for treating water culture, surface of tanks, nets and/ or rearing equipment, but all these equipments would need to rinse off before they could be used in contact with fish.

\section{SUMMARY}

The efficacy of the disinfectant Duplalim ${ }^{\circledR}$, a synergistic blend of superquats and glutaraldehyde, was analysed in vitro against 4 fish pathogens. All concentrations tested (1:200 to 1:400 dilutions) were efficacious on killing Vibrio ordalii and Vibrio anguillarum in seawater after $30 \mathrm{~s}$, being the level of reduction equal to $1.8 \times 10^{6}$ $\mathrm{CFU} / \mathrm{ml}$. Higher concentration of Duplalim ${ }^{\circledR}$ (1:50 dilutions) and time of exposure (at least $5 \mathrm{~min}$ ) is needed to kill completely Francisella $\mathrm{sp}$, an intracellular freshwater pathogen. When Infectious Pancreatic Necrosis Virus (IPNV) was treated with 1:400 disinfectant dilution, this concentration had a significant effect after 2 minutes, regardless of the IPNV titres employed (concentration greater than $10^{7.6} \mathrm{TCID}_{50} / \mathrm{ml}$ ). Duplalim ${ }^{\circledR}$ was tested in large scale against Vibrionaceae members. In comparison to the controls (without the disinfectant), 1:400 dilutions of Duplalim ${ }^{\circledR}$ totally killed $V$. ordalii and $V$. anguillarum in seawater as well as on the surface of the fishing net (used in the cages of cultured salmon) after $15 \mathrm{~min}$. Cultivable bacteria remained constant in the buckets without the disinfectant $\left(1.4 \pm 0.3 \times 10^{6} \mathrm{CFU} / \mathrm{ml}\right)$, regardless of the period sampled. In the case of the adherence on the fishing net, bacteria not exposed to the disinfectant were detected at a concentration of $7.6 \pm 3.2 \times 10^{5} \mathrm{CFU} / \mathrm{ml}$. These data indicate that the use of Duplalim ${ }^{\circledR}$ against $V$. ordalii, V. anguillarum and IPNV is effective in low concentration and short time of exposure (15 min at a concentration of 1:400 dilutions), while the intracellular pathogen requires higher concentration. 


\section{ACKNOWLEDGEMENTS}

This work was supported in part by Grant IPC 019 from the Program Bicentenario Ciencia y Tecnología, CONICYT-Chile and also by Grant DI-01-10/R from the Universidad Andrés Bello.

\section{REFERENCES}

Alderman DJ, TS Hastings. 1998. Antibiotic use in aquaculture: development of antibiotic resistance-potential consumer health risks. Int J Food Sci Technol 33, 139-155.

Austin B, A Austin. 2007. Bacterial fish pathogens: Diseases offarmed and wild fish. Praxis Publishing Ltd, Chichester, UK.

Avendaño-Herrera R, B Magariños, R Irgang, AE Toranzo. 2006. Use of hydrogen peroxide against the fish pathogen Tenacibaculum maritimum and its effect on infected turbot (Scophthalmus maximus). Aquaculture 257, 104-110.

Avendaño-Herrera R, A Silva-Rubio, AE Toranzo. 2007. First report of Vibrio anguillarum in Chilean salmon farms. AFS/ Fish Healt Newsletter 35, 8-10.

Birkbeck TH, M Bordevik, MK Frøystad, M.K, A Baklien. 2007. Identification of Francisella sp. from Atlantic salmon, Salmo salar L. in Chile. J Fish Dis 30, 505-507.

Burka JF, KL Hammell, TE Horsberg, GR Johnson, DJ Rainnie, DJ Speare. 1997. Drugs in salmonid aquaculture - a review. J Vet Pharmacol Therap 20, 333-349.

Colquhoun DJ, IL Aase, C Wallace, Á Baklien, K Gravningen. 2004. First description of Vibrio ordalii from Chile. Bull Eur Ass Fish Pathol 24, 185-188.

Costerton JW, K-J Cheng, GG Geesy, TI Ladd, JC Nickel, M Dasgupta, TJ Marrie. 1987. Bacterial biofilms in nature and disease. Annu Rev Microbiol 41, 435-464.

Costerton JW, Z Lewandowski, DE Caldwell, DR Korber, HM Lappin-Scott. 1995. Microbial biofilms. Annu Rev Microbiol 49, 711-745.

Elliott DG, DF Amend. 1978. Efficiency of certain disinfectants against infectious pancreatic necrosis virus. J Fish Biol 12, 277-286.

Espinoza JC, J Kuznar, 2002. Rapid simultaneous detection and quantitation of infectious pancreatic necrosis virus (IPNV). $J$ Virol Meth 105, 81-85.
Fryer JL, RP Hedrick 2003. Piscirickettsia salmonis: a Gram-negative intracellular bacterial pathogen of fish. J Fish Dis 26, 251-262.

Gibello A, A Mata, M Blanco, A Casamayor, L Domínguez, JF FernándezGarayzábal. 2005. First identification of Streptococcus phocae isolated from Atlantic salmon (Salmo salar). J Clin Microbiol 43, 526-527.

Johansen LH, AI Sommer. 2001. Infectious pancreatic necrosis virus infection in Atlantic salmon Salmo salar postsmolts affects the outcome of secondary infections with infectious salmon anaemia virus or Vibrio salmonicida. Dis Aquat Org 47, 109-117.

Mackelvie RM, D Desautels. 1975. Fish viruses-survival and inactivation of infectious pancreatic necrosis virus. J Fish Res Board Can 32, 1269-1273.

Olsen AB, J Mikalsen, M Rode, A Alfjorden, E Hoel, K Straum-Lie, R Haldorsen, DJ Colquhoun. 2006. A novel systemic granulomatous inflammatory disease in farmed Atlantic cod, Gadus morhua L., associated with a bacterium belonging to the genus Francisella. J Fish Dis 29, 307-311.

Reed LJ, H Muench. 1938. A simple method for estimating fifty percent endpoints. Amer J Hyg 27, 493-497.

Romalde J, C Ravelo, I Valdés, B Magariños, E de la Fuente, C San Martín, R Avendaño-Herrera, AE Toranzo. 2008. Characterization of Streptococcus phocae, an emerging pathogen for salmonid culture. Vet Microbiol 130, 198-207.

Silva-Rubio A, C Acevedo, B Magariños, B Jaureguiberry, AE Toranzo, R Avendaño-Herrera. 2008 ${ }^{\mathrm{a}}$. Antigenic and molecular characterization of Vibrio ordalii strains isolated from Atlantic salmon (Salmo salar) in Chile. Dis Aquat Org 79, 27-35.

Silva-Rubio A, R Avendaño-Herrera, B Jaureguiberry, AE Toranzo, B Magariños. 2008 ${ }^{\text {b }}$. First description of serotype $\mathrm{O} 3$ in Vibrio anguillarum strains isolated from salmonids in Chile. J Fish Dis 31, 235-239.

Smith P, MP Hiney, OB Samuelsen. 1994. Bacterial resistance to antimicrobial agents used in fish farming: a critical evaluation of method and meaning. Annu Rev Fish Dis 4, 273-313.

Verner-Jeffreys DW, CL Joiner, NJ Bagwell, RA Reese, A Husby, PF Dixon. 2009. development of bactericidal and virucidal testing standards for aquaculture disinfectants. Aquaculture 286, 190-197.

Wang S-Y, J Lauritz, Jana, J Jass, DL Milton. 2003. Role for the major outer-membrane protein from Vibrio anguillarum in bile resistance and biofilm formation. Microbiology 149, 1061-1071. 